\title{
The Effect of Summarization Strategies Teaching on Strategy Usage and Narrative Text Summarization Success ${ }^{\mathrm{i}}$
}

\author{
Serpil Özdemir \\ Department of Turkish Language Teaching, Faculty of Education, Bartın University, Bartın, Turkey
}

Copyright(C2018 by authors, all rights reserved. Authors agree that this article remains permanently open access under the terms of the Creative Commons Attribution License 4.0 International License

\begin{abstract}
The purpose of this study is to examine the effect of summarization strategies teaching on usage of summarization strategies and narrative text summarization success. The study was carried out in a single-group pre-test-post-test model without a control group. 35 Turkish teacher candidates participated in the study. Data was collected with Strategies for Text Summarization questionnaire, 140 summary texts which were written by teacher candidates and Text Summary Evaluation Rubric to evaluate these summaries. The experimental process of the study lasted five weeks. As a result of the analysis made, an increase in the usage of summarization strategies and a significant difference in favor of post-test in summarization success were observed. Summarization strategies whereby the most positive change is seen are "determining the main idea, starting the first sentence with an introduction sentence that expresses the subject of the main text, summarizing in accordance with subject or event order and time consistency, expressing the main idea of text in the final sentence of summary, and paying attention to the distinction between the author and the summarizer in the style of the summary text". Summarization is an indication of level of reading comprehension. For this reason, teaching of summarization strategies should be included in reading studies at all levels.
\end{abstract}

Keywords Summarization Strategies, Narrative Text Summarization Success, Turkish Teacher Candidates, Reading, Reading Strategies

\section{Introduction}

In today's conditions where information is rapidly produced and consumed, one of the ways to obtain and remember information when necessary is summarization in order to use time economically. Summarization is the abbreviation of a text based on the main and secondary ideas and its reconstruction by the reader. While the author transfers his own feelings, thoughts and designs to writing in text types, summary is related to trying to understand and rephrasing the feelings, thoughts and designs of another author. Summarizing requires complex cognitive processes such as finding the main idea, associating secondary ideas with the main idea, omitting unnecessary details and organizing main and secondary ideas depending on the main text. Therefore, reading comprehension is the basic element in summary writing.

Summarization provides a significant contribution to students in understanding information and transferring it to long-term memory, as well as improving memory and understanding by ensuring effective use of mental skills [1]. Studies show that students who are successful in reading comprehension are also successful in summarization $[2,3]$ and that teaching of summarization strategies increases comprehension $[4-8,48]$ and enables the things learned to be permanent $[9,48]$. Understanding and remembering are quite important for academic success. For this reason, summarization is used as a learning strategy.

Apart from comprehension skills, explanatory skills are also required in summarization. In summarized texts, the student should paraphrase the essence of the text with as few words as possible and combine the selected parts from the text in the form of short, consistent sentences and paragraphs as much as possible $[10,11]$. The summary text should be written in student's own sentences as far as possible $[12,13]$ because the summary is not a list but a synthesis of selected parts from texts [14]. While writing summary, one should stick to author's ideas [12] and the original text plan [15] without including personal opinions and comments. Simple present tense should be used in a summary [16]. The fact that summarization is quite related with writing skills also contributes to the development of writing skills [4]. It can be said that summarization is not an easy task as it requires both the use of meta-cognitive 
reading strategies and developed writing skills [17].

Summarization is seen by teachers as a task that students can do naturally even though it requires complex cognitive processes. It is neglected to teach students what to pay attention in summarizing $[13,18-21)$. Studies based on summary reviews show that adults can write more successful summaries but readers at all levels still have insufficiencies in writing summary $[11,19,22-24]$. In studies conducted with Turkish teacher candidates, it was seen that teacher candidates were not as successful as they were expected to be in summarization. It was found that they expressed their personal opinions shortly [1], gave unimportant details [25], did not use expression modals correctly [26], not express the main idea of text in the first sentence of summary text [28], not write a new title to summary texts, and not include all important information $[29,30]$. In studies carried out with teachers, it was found that most teachers were not trained at any level about summarization [19] and that teachers lacked knowledge and skills about summarizing [19, 31]. It was specified that there were no learning outcomes related to textual operations such as structuring, generalization and deletion related to summary writing in Turkish course curriculum and accordingly there was no activity in Turkish textbooks [33]. Summarization activities in the textbooks were limited to writing summaries of the texts and text structure was not paid attention in the summarizing activities [20]. These findings show that summarization teaching is neglected at every stage of education and that summarization education should be included at all levels.

Summarization strategy teaching increases usage of summarization strategies and the quality of student summaries. Successful results are achieved especially in finding the main idea and giving details, determining secondary ideas, integrating thoughts, and making generalizations [46]. It is wrong to think that individuals attain this level naturally, but students can be improved by giving importance to teaching summarization strategies.

\subsection{Teaching Summarization Strategies}

Summarization teaching is not asking students to write a summary. It is necessary to teach students what to do, how to do it and which strategies to use. Summarization strategies teaching is done usually within the frame of strategies defined by Brown and Day [22] based on the summarization model developed by Kintsch and Van Dijk. The model developed by Kintsch and Van Dijk [34] handles summarization as forming a macrostructure. A macrostructure is a structure that preserves the general meaning and structure of original text but is free from details. According to this model, every sentence that forms the basis of text and relationship among each sentence forms the microstructure. Deletion, generalization and construction processes are applied to form a macrostructure from microstructures. A sentence is deleted if it is not directly or indirectly related to interpretation of the following sentence. Interrelated concepts in text are generalized by using a more general concept. Each propositional line in text is structured by replacing with global propositions [34]. Thus, a macro-scale structure which preserves the general meaning and structure of the original text but is cleared of details, in other words summary is reached. Based on this model, Brown and Day [22] identified six strategies. These strategies include deleting unimportant material, deleting unnecessary material even if it is important, presenting sentences and lists of statements with a general expression, using an action that generalizes it instead of its subcomponents, choosing subject sentence in the text if any and forming subject sentence if there is none in the text.

\subsubsection{Text Structure}

In summarization teaching, it is also important to know other texts structures apart from knowing summarization strategies [34]. Explanatory and narrative texts have different structures. Summary is an abbreviation made by preserving original structure of the main text. For this reason, it is necessary for the students to know text structures for a good summary. The narrative text is written to make the reader feel him/herself in an event. An event or chain of events is conveyed from the point of view of a narrator depending on place, time and people. The components of narrative expression structure are "state, event, the first reaction, attempt, result and reaction". The situation element contains the place, time and people; event is the basic problem, the first reaction is the initial reaction of main character to the main event, attempt is what the main character does to solve the problem, result is whether the main character has solved the problem or not, reaction is the situation of main character considering the result. Summarization of narrative texts aims not to make the reader feel him/herself in the event, but to give information about that text. The summary of the narrative text is structured in introduction, development and conclusion paragraphs. Situation element and main idea of narrative are included in the introduction; event, first reaction and attempt are included in the development while result and reaction elements of narrative are included in the conclusion [35, cited in 47). Explanatory texts are written for the purpose of providing information and carry different structural features such as defining/description, comparison and equating, chronological ordering, problem solving, process definition and cause-effect depending on presentation style of information [36]. In summarization of explanatory texts, elements such as ordering, solution of problem, causes and results are given depending on the way the source text presents information. When summarizing explanatory texts, a hierarchical approach is usually used. "The hierarchical summarization consists of first preparing a skeleton outline based on headings, subheadings, and paragraphs, and then writing a main idea 
statement for every point on the outline." [37]. It is easier to pick important ideas from narrative texts than it is to pick from other texts [38]. In the study conducted by Bulut [19], it was found that narrative text summarization success is higher than summarization success achieved in informative texts and more summarization strategies are used in narrative text summaries. Based on the principle of "from simple to complex", priority should be given to narrative texts in summarization studies. Brown and Day [22] suggests that firstly simple, then complex narratives should be selected when selecting narrative texts. Following narrative text summarization studies, summarization of texts with different structures should also be included in teaching because different strategies are used to summarize different texts structures $[39,40]$.

\subsubsection{Summarization Process}

Summarization is a writing exercise which is based on reading comprehension. Writing exercises are carried out by taking into consideration strategies applied before, during and after writing. Summarization studies are done in a similar way to other writing studies. Text reading and comprehension and note-taking are performed before writing in order to prepare students for summarization, abbreviation of the source text using summarization strategies is performed during writing, and reviewing the coherence of original text and summary is performed after writing [41, 32]. In the development of summarization skills, analyzing good and bad summaries of texts and doing exercises on completing missing summary texts before beginning summarization process will ensure that texts to be summarized are perceived and qualities of a good summary are seen concretely [41].

Benzer et al. [27] conducted a four-week study with students by determining the strategies used before, during, and after writing. At the end of this study, they developed a text summarization strategy that consisted of strategies that were found to be fit to be used by students. There are the following strategies before writing: reading the text carefully, underscoring key words in each paragraph, identifying secondary ideas which support the main idea in each paragraph, making brief informatory notes to be used in summary, and identifying the main idea. Strategies used during writing are firstly writing the title of summary, starting the first sentence with an introduction sentence that expresses subject of the main text, summarizing the brief informatory notes that were underscored before with a few sentences, creating the summary in accordance with subject or event order and time coherence, expressing the main idea of the text in the final sentence of summary. Post-writing strategies are reading the summary once more by paying attention to harmony with idea or plot in the main text, omitting the sentences which are out of context and contain unnecessary information if any, adding sentences if there are any missing in ensuring meaning integrity, paying attention to the distinction between writer and the summarizer in style, checking grammar and punctuation marks and if necessary correcting them, and asking someone else to read and evaluate the summary if possible. This research is based on the summarization strategy developed by Benzer et al. [27] as it takes into account the strategies before, during, and after writing.

\subsection{Importance of the Research}

Research carried out with Turkish teacher candidates aim to determine the summarization strategies used in content of written summary with qualitative data analysis $[26,42,25,30,1,24,31)$, identify the summarization strategies usage trend by scanning model [43, 28] and develop text summary writing strategy and rubric [27]. An experimental study with Turkish teacher candidates based on the teaching of summarization strategies was not found. This study is unique in this respect. Summarization is one of the learning strategies which should be utilized in all lessons, notably language lessons. The lesson where summarization strategies will be learnt is primarily Turkish lesson. Turkish teacher candidates who will be responsible for developing summarization skills of students should be equipped with the necessary knowledge and skills. It is envisaged that the results obtained from this study would be a guide to raise Turkish teacher candidates and to teach summarization strategies to teachers.

\subsection{The Purpose of the Research}

Understanding new information and remembering it when necessary are crucial for academic success. Summarization is a learning strategy that increases both understanding and memory. Strategy learning is based on taking as model. The better the ability of the teacher to summarize is, the better the student will be. In this context, the research aims to determine how summarization strategy teaching affects Turkish teacher candidates' use of summarization strategies and success in narrative text summarization.

The research was handled with the following sub-problems:

1. How often is summarization strategy used in the pre and post-test?

2. How is weekly progress in summarizing success?

3. Is there a meaningful difference between pre-test and post-test in summarization success?

\section{Method}

The research was carried out with a single-group pre-test-post-test model from pre-experimental models. In this model, independent variable is applied to a randomly selected group. Measurements are performed before and after the experiment. If post-test scores are higher than pre-test scores, it is acknowledged that it is because of 
independent variable [44]. In this study, training of summarization strategies was considered as an independent variable and strategy use and summarization success as dependent variables.

\subsection{Procedure}

In the first week, no information was given on summarization strategies. The Strategies for Text Summarization (STM) Questionnaire was given as a pre-test to determine the use of summarization strategies. Then the story called Eskici was summarized. These first summaries were evaluated as summarization success pre-test.

In the second week summarization strategies were taught. While teaching summarizing strategies, the answers to questions: "What is summary, what are summarization strategies, what are the benefits of strategies, what is the difference between story and story summary?" were dwelt on. The examples on how to use summarization strategies were shown on the previous week's story. Successful and unsuccessful examples were selected from the summaries of students. These examples were projected and the reasons for their success or failure were discussed. Then researchers' evaluations of summaries of the previous week were given to the students. These evaluations were made with rubric and feedback was written on summary text. The rubric was provided along with the summary to each student to enable them to see their mistakes and correct aspects. Then they were asked to exchange their summaries with their peers for review and suggestions. Finally, they were asked to summarize a new story.

In the third, fourth and fifth weeks, activities carried out in second week were repeated in a similar way. Summarizing strategies teaching was continued by dwelling on non-developing strategies. Summaries written in the fourth week were evaluated as summarization success post-test. A new story was summarized in the fifth week and the STM questionnaire was repeated as a post-test. The research is based on 10 hours of work in total.

\subsection{Study Group}

Study was carried out with 3rd grade students of Turkish language teaching who study in a faculty of education in the Western Black Sea in the academic year 2017-2018. Since study topic was suitable for the purposes of text production techniques course, study was carried out by students who took this course. Text production techniques courses were 2 hours per week. Since this course was carried out by the researcher, the selection of the sample bears an easily accessible sampling feature. "In this method, the researcher chooses a situation that is easy to access" [45]. 35 students who took this course participated in the study.

\subsection{Data Collection Tool}

The research data was collected with the STM questionnaire, summary texts written by the teacher candidates and the Text Summary Evaluation Rubric (TSER) to evaluate these summaries.

STM and TSER were developed simultaneously by Benzer, et al. [27] in the study process that was student-oriented and lasted four weeks. In the development of STM and TSER, literature review on writing text summary was performed and criteria were determined. Then researchers suggested new criteria related to subject and a pool of items was created. STM and TSER were created from appropriate items in this pool. During the implementation period, improvement-oriented changes were made in the STM and TSER in accordance with opinions of students gathering weekly and researcher observation notes. Thus, with a student-centered mindset, criteria that did not prove to be effective were improved during the process, non-improvable ones were excluded, ones which were partially-effective were developed, and ones which proved to be effective were maintained. After this reforming study, the criteria were ordered logically, harmonized and a smoothly-functioning organization structure was established. Opinions of two Turkish teachers and four field experts were taken to ensure validity of TSER. The reliability of TSER was established by reproducing five randomly-selected summary texts, sending them to four independent researchers, and evaluating the results received from them. The agreement among results of researchers was found to be $90 \%$.

TSER, which was used in the study is seen in Table 1

The STM that is created by Benzer, et al. [27] is in the form of a list. Strategy sentences have been turned into expressions of self-efficacy so that they can be used for the purpose of this study. For example, the sentence of "The text should be read carefully." in the original study has been expressed as "I carefully read the text." in this study; while the sentence of "The title of the summary should be written first." is expressed as "I write the title of the summary first." The ratings of "I agree, I agree partially, I do not agree" are written at the opposite of each sentence. Thus, the strategy sentences which are determined by Benzer, et al [27] have been arranged as a survey to measure summarization strategies. The reorganized Summarized Strategies Survey has been shared with the researchers who developed STM list and permission has been taken for use in this study. 
Table 1. Text summary evaluation rubric

\begin{tabular}{|c|c|c|c|c|}
\hline Theme & Criteria & Inadequate (1p.) & Need to improve (2p.) & Successful (3p.) \\
\hline \multirow{3}{*}{ SHAPE } & Paper order & $\begin{array}{l}\text { Paper order is not } \\
\text { respected. }\end{array}$ & $\begin{array}{l}\text { Paper order is not respected } \\
\text { partially. }\end{array}$ & $\begin{array}{l}\text { Paper order is sufficient and } \\
\text { placed on center. }\end{array}$ \\
\hline & Paragraph number & $\begin{array}{l}\text { Summary text consists of } \\
7 \text { or more paragraphs. }\end{array}$ & $\begin{array}{l}\text { Summary text consists of 4-6 } \\
\text { paragraphs. }\end{array}$ & $\begin{array}{l}\text { Summary text consists of 1-3 } \\
\text { paragraphs. }\end{array}$ \\
\hline & $\begin{array}{l}\text { Grammar, punctuation, } \\
\text { spelling }\end{array}$ & $\begin{array}{l}6 \text { and more grammar, } \\
\text { punctuation, spelling } \\
\text { mistakes have been done. }\end{array}$ & $\begin{array}{l}\text { 3-5 grammar, punctuation, } \\
\text { spelling mistakes have been } \\
\text { done. }\end{array}$ & $\begin{array}{l}\text { 1-2 grammar, punctuation, } \\
\text { spelling mistakes have been } \\
\text { done. }\end{array}$ \\
\hline \multirow{7}{*}{ CONTENT } & Content integrity & $\begin{array}{l}\text { Content integrity is not } \\
\text { respected. }\end{array}$ & $\begin{array}{l}\text { Content integrity is not } \\
\text { respected partially. }\end{array}$ & Content integrity is satisfied. \\
\hline & Introduction sentence & $\begin{array}{c}\text { There is no introduction } \\
\text { sentence. }\end{array}$ & $\begin{array}{c}\text { Introduction sentence is } \\
\text { inadequate. }\end{array}$ & $\begin{array}{l}\text { Introduction sentence gives } \\
\text { topic of text. }\end{array}$ \\
\hline & Plot & $\begin{array}{l}\text { In summary topic and } \\
\text { event order is not paid } \\
\text { attention. }\end{array}$ & $\begin{array}{l}\text { In summary topic and event } \\
\text { order messed. }\end{array}$ & $\begin{array}{l}\text { In summary topic and event } \\
\text { order is given in correct way. }\end{array}$ \\
\hline & Side ideas/events & $\begin{array}{l}\text { Side ideas/events are not } \\
\text { written. }\end{array}$ & $\begin{array}{l}\text { Side ideas/events are written } \\
\text { lack. }\end{array}$ & Side ideas/events are written. \\
\hline & Details & $\begin{array}{l}\text { Unnecessary details and } \\
\text { unrelated information with } \\
\text { topic are written. }\end{array}$ & $\begin{array}{l}\text { Unnecessary details and } \\
\text { unrelated information with } \\
\text { topic are given less. }\end{array}$ & $\begin{array}{l}\text { Details and unrelated } \\
\text { information with topic aren't } \\
\text { given. }\end{array}$ \\
\hline & Use of key words & $\begin{array}{l}\text { Key words have not been } \\
\text { mentioned. }\end{array}$ & $\begin{array}{l}\text { Some of key words have not } \\
\text { been mentioned. }\end{array}$ & $\begin{array}{l}\text { All key words have been } \\
\text { mentioned. }\end{array}$ \\
\hline & Main idea & $\begin{array}{l}\text { Main idea has not been } \\
\text { issued. }\end{array}$ & $\begin{array}{l}\text { Main idea has been issued } \\
\text { partially. }\end{array}$ & $\begin{array}{c}\text { Main idea has been } \\
\text { determined. }\end{array}$ \\
\hline \multirow[b]{2}{*}{ STYLE } & Use of time suffixes & $\begin{array}{l}\text { Time suffixes have been } \\
\text { used as incompatible. }\end{array}$ & $\begin{array}{l}\text { Some of time suffixes have } \\
\text { been used as incompatible. }\end{array}$ & $\begin{array}{c}\text { Time suffixes have been used } \\
\text { as compatible. }\end{array}$ \\
\hline & $\begin{array}{l}\text { Direct citation or } \\
\quad \text { imitation }\end{array}$ & $\begin{array}{l}\text { It consists of direct citation } \\
\text { or imitations from main } \\
\text { text. }\end{array}$ & $\begin{array}{l}\text { It consists of less sentences } \\
\text { which makes direct citation } \\
\text { or imitations from main text. }\end{array}$ & $\begin{array}{l}\text { It is written with own } \\
\text { expression of reader. }\end{array}$ \\
\hline
\end{tabular}

Table 2. Information on summarized texts

\begin{tabular}{ccccc}
\hline Summarized Text & Eskici & $\begin{array}{c}\text { Karanfiller ve } \\
\text { Domates Suyu }\end{array}$ & Vitrindeki Masal Kitabı & Miras Keçe \\
\hline Word number & 928 & 824 & 742 & 955 \\
Sentence number & 79 & 79 & 93 & 118 \\
Paragraph number & 49 & 17 & 30 & 50 \\
Author & Refik Halit Karay & Sait Faik Abasıyanık & Üzeyir Gündüz & Kenan Hulusi Koray \\
& MoNE (2015). 6. & MoNE (2015). 8. & MoNE (2015) 6. Grade & MoNE (2015). 7. Grade \\
Resource & Grade Turkish & Grade Turkish & Turkish Textbook & Turkish Textbook \\
& Textbook & Textbook & &
\end{tabular}

The summaries written by teacher candidates have been used as data collection tools to measure the summarization success in the study. The narrative texts belonging to classical authors of Turkish Literature have been summarized by teacher candidates. Classical texts are texts that are likely to be included in new course books, even when the book's contents change. However, these texts have not been taken from original source; they are taken from secondary school Turkish course books. Since the purpose of this study is not to test the comprehension abilities of candidate teachers, the original texts are not preferred. Attention has been paid to select texts from writers who write for adults. Thus, it is aimed that teacher candidates learn practical information on possible texts that they would encounter at work. A total of 10 narrative texts have been selected from textbooks. Selected texts are presented to the opinions of 5 Turkish teaching experts. At this stage, experts have been asked to rate texts according to criteria of "intensity of events / thoughts, relaying of events through dialogue, including descriptions, text length". The rating has been made as 3 points for "eligible", 2 points for "partially eligible" and 1 point for "not eligible". 4 texts that were deemed eligible by all of the experts are used in summarization work. Information on summarized texts is presented in Table 2 .

As seen in Table 2, texts are included in MoNE (Ministry of National Education) Turkish textbooks of different grade levels. The word number of the texts range from 742 to 955 , the number of sentences ranges from 79 to 118 , and the number of paragraphs ranges from 17 to 50. Eskici which is one of the two closest texts in terms of word and paragraph count is used as pre-test to determine summarization success, and Miras Keçe, the other one, is used as post-test.

Two methods were used to ensure reliability in the measuring of summarization success: Firstly, all of the 
texts were evaluated regularly by the researcher on weekly basis. Randomly selected 30 summaries were reevaluated by the researcher three weeks after the experimental study ended. The relation between these evaluation scores was examined by Spearman correlation coefficient. Correlation coefficient for all measures was found between 0.90 and 0.92 . Secondly, a total of 32 summaries of eight randomly selected students were evaluated by a Turkish language teaching expert. Correlation coefficients between researcher and expert scores were found to be between 0.87 and 0.91 for all criteria. Positive and high correlation coefficients indicated that the measurement was reliable.

\subsection{Data Analysis}

Descriptive analysis has been performed to determine the frequency of use regarding summarization strategies and weekly development of summarization success. In summarization success, Wilcoxon Signed Rank Test have been applied to matched groups to determine whether there is a significant difference between pre-test and post-test. Non-parametric tests have been conducted since it is determined that summarization success scores are not distributed normally.

\section{Results}

The study's primary sub-problem aims to determine the usage frequency of summarization strategies by teacher candidates before and after their summarization strategies training. The frequency analysis has been performed for this purpose and is provided in Table 3 .

Table 3. Summarization strategies usage frequency in pre-test and post-test

\begin{tabular}{|c|c|c|c|c|c|c|c|}
\hline & & \multicolumn{2}{|c|}{ I agree } & \multicolumn{2}{|c|}{ I agree partially } & \multicolumn{2}{|c|}{ I don't agree } \\
\hline & & Pre & Last & Pre & Last & Pre & Last \\
\hline & & $\mathbf{f} / \%$ & $\mathbf{f} / \%$ & $\mathbf{f} / \%$ & $\mathbf{f} / \%$ & $\mathbf{f} / \%$ & $\mathbf{f} / \%$ \\
\hline \multirow{5}{*}{$\begin{array}{l}\text { Before } \\
\text { writing } \\
\text { summary }\end{array}$} & I read text carefully. & $35 / 100$ & $35 / 100$ & $0 / 0$ & $0 / 0$ & $0 / 0$ & $0 / 0$ \\
\hline & $\begin{array}{l}\text { I underline key words in every } \\
\text { paragraph. }\end{array}$ & $8 / 22,9$ & $13 / 37,1$ & $7 / 20$ & $12 / 34,1$ & $20 / 57,1$ & $10 / 28,6$ \\
\hline & $\begin{array}{l}\text { I specify side ideas which support main } \\
\text { idea in every paragraph. }\end{array}$ & $7 / 20$ & $10 / 28,6$ & $17 / 48,6$ & $24 / 68,6$ & $11 / 31,4$ & $1 / 2,9$ \\
\hline & $\begin{array}{l}\text { I form brief information notes to use in } \\
\text { summary. }\end{array}$ & $6 / 17,1$ & $11 / 31,4$ & $5 / 14,3$ & $9 / 25,7$ & $24 / 68,6$ & $15 / 42,9$ \\
\hline & I determine main idea. & $10 / 28,6$ & $32 / 91,4$ & $4 / 11,4$ & $3 / 8,6$ & $21 / 60$ & $\mathbf{0} / \mathbf{0}$ \\
\hline \multirow{5}{*}{$\begin{array}{l}\text { During } \\
\text { writing } \\
\text { summary }\end{array}$} & Firstly, I write title of summary. & $22 / 62,9$ & $30 / 85,7$ & $9 / 25,7$ & $3 / 8,6$ & $4 / 11,4$ & $2 / 5,7$ \\
\hline & $\begin{array}{l}\text { I start with an introduction sentence } \\
\text { which expresses topic of main text to } \\
\text { the first sentence. }\end{array}$ & $4 / 11,4$ & $31 / 88,6$ & $9 / 25,7$ & $4 / 11,4$ & $22 / 62,9$ & $0 / 0$ \\
\hline & $\begin{array}{l}\text { I summarize brief information notes } \\
\text { which I underline before in two } \\
\text { sentences. }\end{array}$ & $9 / 25,7$ & $16 / 45,7$ & $4 / 11,4$ & $9 / 25,7$ & $22 / 62,9$ & $10 / 28,6$ \\
\hline & $\begin{array}{l}\text { I form summary according to topic or } \\
\text { event order and time coherence. }\end{array}$ & $19 / 54,3$ & $31 / 88,6$ & $7 / 20$ & $4 / 11,4$ & $9 / 25,7$ & $0 / 0$ \\
\hline & $\begin{array}{c}\text { I express main idea of text in last } \\
\text { sentence of summary. }\end{array}$ & $5 / 14,3$ & $34 / 97,1$ & $3 / 8,6$ & $1 / 2,9$ & $27 / 77,1$ & $0 / 0$ \\
\hline \multirow{5}{*}{$\begin{array}{l}\text { After writing } \\
\text { summary }\end{array}$} & $\begin{array}{c}\text { I pay attention to thought order and plot } \\
\text { harmony in main text by reading it } \\
\text { again. }\end{array}$ & $22 / 62,9$ & $28 / 80$ & $9 / 25,7$ & $7 / 20$ & $4 / 11,4$ & $0 / 0$ \\
\hline & $\begin{array}{l}\text { If there is any sentence which is out of } \\
\text { text or contain unnecessary information, } \\
\text { I eliminate it. If there is any missing } \\
\text { sentence for meaning integrity, I add it. }\end{array}$ & $12 / 34,3$ & $18 / 51,4$ & $14 / 40$ & $15 / 42,9$ & $9 / 25,7$ & $2 / 5,7$ \\
\hline & $\begin{array}{c}\text { In style of summary text, I pay } \\
\text { attention to distinction of narrator } \\
\text { and author. }\end{array}$ & $10 / 28,6$ & $26 / 74,3$ & $18 / 51,4$ & $9 / 25,7$ & $7 / 20$ & $0 / 0$ \\
\hline & $\begin{array}{l}\text { I check grammar and punctuation rules } \\
\text { of summary text, if necessary I correct } \\
\text { it. }\end{array}$ & $15 / 42,9$ & $26 / 74,3$ & $13 / 37,1$ & $7 / 20$ & $7 / 20$ & $2 / 5,7$ \\
\hline & $\begin{array}{l}\text { If there is an opportunity, I read my } \\
\text { summary to others in order to evaluate } \\
\text { and receive feedback. }\end{array}$ & $16 / 45,7$ & $18 / 51,4$ & $11 / 31,4$ & $16 / 45,7$ & $8 / 22,9$ & $1 / 2,9$ \\
\hline
\end{tabular}

As seen in Table 3, the strategy of careful text reading is used by all students. There is an increase in all other strategies after the teaching of summarization strategies. We see increase the most in the following strategies; "Specifying main idea, starting the first sentence with an introduction sentence that expresses the topic of main text; 
forming summary in accordance with topic, event order and time coherence, expressing main idea of text in the last sentence of summary, paying attention to the distinction between author and summarizer regarding the style of the summary text". We see increase the least in the following strategies; "Underlining the key words in each paragraph, identifying secondary ideas in each paragraph that support the main idea, creating brief information notes to be used in summary, summarizing brief information notes that have been underlined in a few sentences, reading the summary again and having other people read the summary".

The second sub-problem of study is to determine weekly progression in summarization success. The frequency analysis of weekly evaluation with TSER is shown in Table 4.

Table 4. Weekly progressions in summarization success

\begin{tabular}{|c|c|c|c|c|c|c|c|c|c|c|c|c|c|}
\hline & \multirow[t]{2}{*}{ Criteria } & \multicolumn{4}{|c|}{ Inadequate (f) } & \multicolumn{4}{|c|}{ Need to improve (f) } & \multicolumn{4}{|c|}{ Successful (f) } \\
\hline \multirow{5}{*}{ Shape } & & 1.w. & 2.w. & 3.w. & 4.w. & 1.w. & 2.w. & 3.w. & 4.w. & 1.w. & 2.w. & 3.w. & 4.w. \\
\hline & 1.Paper Order & 11 & 5 & 4 & 1 & 15 & 11 & 10 & 8 & 9 & 19 & 21 & 26 \\
\hline & 2.Paragraph number & & & & & & & & & & & & \\
\hline & 3.Grammar, & 19 & 14 & 3 & 2 & 13 & 8 & 20 & 7 & 3 & 13 & 12 & 26 \\
\hline & $\begin{array}{l}\text { punctuation, } \\
\text { spelling }\end{array}$ & 15 & 10 & 2 & 3 & 12 & 13 & 11 & 14 & 8 & 12 & 22 & 18 \\
\hline \multirow{7}{*}{ Content } & 4.Meaning integrity & 12 & 15 & 1 & 0 & 12 & 17 & 24 & 11 & 11 & 3 & 10 & 24 \\
\hline & $\begin{array}{l}\text { 5.İntroduction } \\
\text { sentence }\end{array}$ & 29 & 19 & 5 & 7 & 4 & 7 & 9 & 4 & 2 & 9 & 21 & 24 \\
\hline & 6.Plot & 14 & 13 & 2 & 0 & 14 & 19 & 25 & 16 & 7 & 3 & 8 & 19 \\
\hline & 7.Side ideas & 18 & 12 & 2 & 0 & 12 & 21 & 22 & 10 & 5 & 2 & 11 & 25 \\
\hline & 8.Details & 21 & 15 & 3 & 0 & 6 & 14 & 26 & 19 & 8 & 6 & 6 & 16 \\
\hline & $\begin{array}{l}\text { 9.Usage of key } \\
\text { words }\end{array}$ & 14 & 13 & 1 & 0 & 14 & 17 & 18 & 9 & 7 & 3 & 16 & 26 \\
\hline & 10.Main idea & 30 & 5 & 3 & 1 & 3 & 15 & 7 & 1 & 2 & 15 & 25 & 33 \\
\hline \multirow{2}{*}{ Style } & $\begin{array}{l}\text { 11. Usage of time } \\
\text { suffixes }\end{array}$ & 14 & 11 & 12 & 3 & 12 & 3 & 2 & 4 & 9 & 21 & 21 & 28 \\
\hline & $\begin{array}{l}\text { 12. Direct citation } \\
\text { or imitation }\end{array}$ & 15 & 1 & 1 & 0 & 9 & 7 & 8 & 11 & 11 & 27 & 26 & 24 \\
\hline
\end{tabular}

Table 4 demonstrates that students who have inadequate summarization success decrease regularly except in content integrity criterion, successful students decrease especially in the second week in terms of content and increase in fourth week in all criteria. It is noteworthy that students who are inadequate at shape criteria exist in $4^{\text {th }}$ week in small numbers, and among the criteria related to content, 7 students are inadequate in terms of introduction sentences, 1 student is inadequate in main idea criterion, and 3 students are inadequate in the use of time suffixes, which is a criterion related to style.

The weekly development of evaluations, which were performed based on a total of 12 criteria, in terms of criterion averages is shown in Figure 1.

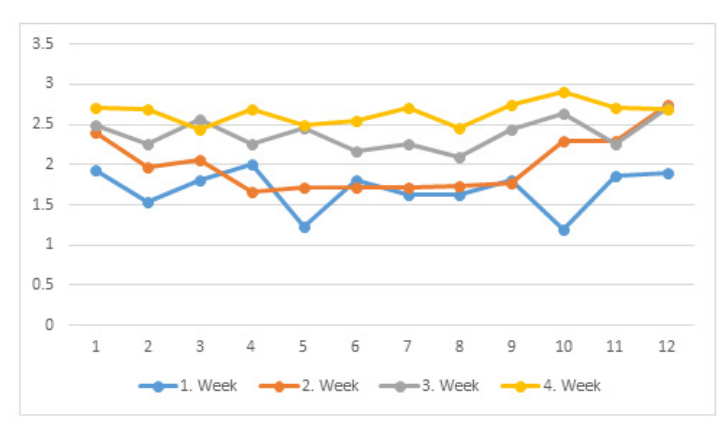

Figure 1. Weekly development in TSER criteria
In Figure 1, the bottom line shows the first week, while the top line shows the fourth week. The average of the first week is below 2 in all criteria. In particular, it seems that the criteria of writing an introduction sentence and a main idea to summary are rarely used. The development of the first three and the last three criteria in the second week is remarkable. The first three criteria are related to form. It is seen there is a development in terms of paper layout, number of paragraphs, grammar, punctuation and spelling. The last three criteria are the main idea, the use of time suffixes, avoiding direct citation and imitation. The average of these criteria is less than 2 in the first week and exceeded 2 at the 2 nd week. The direct citation or imitation avoidance success rate, which is the $12^{\text {th }}$ criterion, has increased to the maximum level at 2nd week. It is noteworthy that there is no improvement in terms of content at 2 nd week. The improvement in content has begun at week 3 and continued to increase at week 4 . At week 4 , the success in the criterion of meaning integrity, plot, secondary ideas, use of key words and main idea have reached the highest level.

Weekly success average was also evaluated. Qualitative analyze related to success average is seen in Table 5 .

Table 5 shows that the summarization success averages increase regularly. The paired samples $t$ test has been 
performed for the third sub-problem which aims to determine whether this increase shows a meaningful difference between pre-test and post-test in summarization success. The results of the test are shown in Table 6.

Table 5. Weekly success average

\begin{tabular}{cccccc}
\hline Week & N & Mean & Std. D & Min. & Max. \\
\hline 1.w & 35 & 1,693 &, 4301 & 1,08 & 2,67 \\
2.w & 35 & 2,005 &, 4381 & 1,25 & 3,00 \\
3.w & 35 & 2,381 &, 3508 & 1,25 & 3,00 \\
4.w & 35 & 2,648 &, 2964 & 1,92 & 3,00 \\
\hline
\end{tabular}

Table 6. Pre-test and Post-test scores on summarization success

\begin{tabular}{cccccc}
\hline Pre-Post-test & N & $\begin{array}{c}\text { Mean } \\
\text { Rank }\end{array}$ & $\begin{array}{c}\text { Sum of } \\
\text { Ranks }\end{array}$ & $\mathbf{z}$ & $\mathbf{p}$ \\
\hline Negative Orders & 1 & 1 & 1 & $-5,072$ &, 000 \\
Positive Orders & 33 & 18 & 594 & & \\
No difference & 1 & & & & \\
\hline
\end{tabular}

As seen in Table 6 there is a significant difference between summarization successes of the students who participated in study before and after the teaching strategy $[z=-5,072, p<0,05]$. When mean rank and sum of rank are taken into consideration, the difference is in favor of positive order, or namely, post-test. According to this result, it can be said that teaching of summarization strategies has a meaningful effect on the success of writing summaries.

\section{Discussion and Conclusions}

In this study, the effect of the teaching summarization strategies on the use of summarization strategies and narrative text summarization success of Turkish teacher candidates has been investigated. Data have been collected with STM survey, a total of 140 summary texts written by teacher candidates and TSER to evaluate these summaries. As a result of conducted analyzes, it was determined that use of summarization strategies and summarization success have increased.

\section{Usage of Summarization Strategies}

It was seen that the strategy regarding the careful reading of text was used by all students in pre-test and post-test. All other strategies showed an increase in post-test.

\section{Before writing a summary}

Even though there is an increase in the number of students who use strategies of underlining key words in each paragraph, identifying secondary ideas that support main idea and forming brief summary notes to use in summary; it is not at the desired level. The post-test has indicated that 10 students did not use strategies to underline the key words in paragraphs, while 15 students did not make brief information notes to use in summary. Note taking strategies were introduced and exemplified during the study. However, students were only recommended to use these strategies. The reasons for the scarce use of strategies regarding taking information notes and note taking can be cited as: the fact that the study group consists of adults, that they believe they have no problems in comprehending what they read, source texts are composed of stories and are easy to understand. The number of students who absolutely use the strategy of finding the main idea was 10 in pre-test and increased to 32 in post-test. Identifying the main idea is one of the strategies which differed greatly due to teaching of summarization strategies.

\section{During the writing of a summary}

The increase in post-test is remarkable in terms of number of students who indicate that they absolutely agree with strategies of starting the first sentence with an introduction sentence that expresses topic of main text (4/31), paying attention to order of subject or event and time coherence (19/31), expressing main idea of text in the final sentence of summary $(5 / 34)$. These are the strategies that teaching of summarization strategies created the most difference. In the post-test 10 students stated that they did not use the strategy of summarizing the brief information notes, which were underlined before, in one or two sentences. Students who do not tend to use this strategy before writing a summary do not have notes to use when writing a summary. This strategy is one of the strategies that developed the least.

After writing a summary; a remarkable increase was observed in the number of students who stated that they absolutely use a strategy of paying attention to the distinction between author and summarizer in the style of summary text (10/26). An increase in post-test was seen in the number of students who state they absolutely use the strategies of eliminating non-textual and unnecessary information, adding sentences to ensure meaning integrity $(12 / 18)$. However, there were also students who partially $(\mathrm{f}=15)$ or never $(\mathrm{f}=2)$ use them. A similar situation was seen in the strategy of checking and if necessary, correcting the grammar and punctuation marks of the summary. There were students who use this strategy partially $(\mathrm{f}=7)$ and those that never use $(\mathrm{f}=2)$ them in the post-test. The strategy of asking someone to read and evaluate the summary is one of the strategies which was seen the least development. It was seen that there were students who partially $(\mathrm{f}=16)$ and never use $(\mathrm{f}=1)$ this strategy in the post-test.

When changes in the use of strategy are collectively revised, it is noteworthy that the teaching of strategies has created an improvement in the tendency of teacher candidates to use strategies to comprehend the source text, 
write a summary that represents the content and structure of the source text. There is less improvement in the tendency to use the strategies of note-taking and then revising it, which are related to summarizer attitudes.

\section{Summarization Success}

It is seen that "Inadequate" students have regularly decreased in the weekly development of summarization success, except for the criterion of content integrity. The findings regarding the success in ensuring meaning integrity overlap with the findings regarding the perception of students about the use of this strategy. The relevance of grammatical transitions and text construction of summarizer without giving any personal opinion has been evaluated in content integrity criterion. Ability of students to summarize with correct sentences and without deviating from author's writings has been one of the hardest abilities to develop. Yazıcı Okuyan and Gedikoğlu [31] have determined that half of teachers are at an adequate level in this topic. Susar and Akkaya [1] found that teacher candidates have included ideas that were unrelated with text. These findings show that abilities of both teacher candidates and teachers about summarizing are lacking.

When the weekly development of summarization success is examined, it is seen that content success is decreased in the second week, and success is increased in all criteria in the fourth week. The decrease in success at second week's summaries can be explained based on two factors. At the end of strategy teaching, students realized that they made many mistakes which they thought to be correct. It is thought that this situation led to loss of confidence and confusion in some students. Success in the third summarization study since the beginning of strategy teaching became closer to desired level. This situation proved that summarization success cannot be improved easily and that the teaching and summarizing work must be conducted repeatedly. Furthermore, students have stated that it is difficult to summarize the source text in the second week due to author's style. Upon the evaluation of these results in terms of summarization studies, it is suggested that the selection of text should not be limited by expert opinion, and it is more suitable to choose text by pre-implementation. Selection of text based on expert opinion is one of the limitations of the study.

A weekly and regular improvement in details criterion of summarization success was not achieved. For four weeks, $8,6,6,16$ students have been found as successful respectively. 18 students have stated that they definitely agree with strategies of eliminating sentences which have unnecessary information and adding sentences to provide meaning integrity in post-test. Success grades and test results of strategy use are compatible in this respect. However, this result shows that students are not fully developed in eliminating unnecessary details. It is not easy to increase success at this topic because of the difficulties students face in determining what detail in the text is. Students have begun to exclude important elements while avoiding giving details. This has led to emergence of summaries that do not fully represent the source text. There are studies that show that Turkish teacher candidates are not successful enough about strategies in terms of choosing important knowledge and deleting unimportant information $(27,26]$. Kurnaz and Akaydın [30] determined that $24 \%$ of teacher candidates are proficient in the strategy of deleting unnecessary information, while this was $26 \%$ in the study Ülper and Yazıc1 Okuyan [24] and 29\% in the study of Yazıc1 Okuyan and Gedikoglu [31]. Karatay and Okur [25] has determined that Turkish teacher candidates are not proficient in terms of information deletion. Deletion is the simplest and most common macrostructure rule [22]. This situation demonstrates the necessity for including the teaching of summarization strategies starting from primary school. A student who internalizes this knowledge throughout their education process would be at a level that can distinguish important and unimportant information when they become students at a university.

In spite of these mentioned problems, remarkable increase has been seen in the number of students who were successful in pre-test and post-test in the criteria for "Paper order (9/26), number of paragraphs (3/26), introduction sentences $(2 / 24)$, plot (7/19), secondary ideas $(5 / 25)$, use of keywords (7/26), main idea (2/33), use of time suffixes (9/28), direct citation or imitation (11/24) ". There were no inadequate students in terms of "meaning integrity, plot, secondary ideas, and details, use of key words, direct citation or imitation" criteria. The "introduction sentence" was the criteria which the greatest numbers of students were at an inadequate level (7). The results of this study mostly overlap with the study conducted by Benzer et al. [27]. Based on these results, it can be said that the teaching of summarization strategies has improved the ability to summarize in many ways.

It can be seen that the success of summarization has increased regularly when weekly averages in summarization success are taken into consideration. The first week has stayed below an average of 2 on all criteria. In particular, it has been determined that criteria of writing an introduction sentence and main idea are rarely used. In the second week, the average has increased above 2 in terms of style and for the criteria of the use of main ideas, time suffixes, avoiding direct citation and imitation. There is no improvement for content-related criteria at week 2 . The development related to content has begun at week 3 and continued at week $4.4^{\text {th }}$ week has seen the highest level of success for the criteria of meaning integrity, plot, secondary ideas, use of key words and main idea. This indicates that summarization strategies teaching for the teacher candidates should continue at least three weeks.

In the pre-test-post-test comparison the difference 
between averages has been found to be significant in favor of post-test. According to this finding, it can be said that the teaching of summarization strategies has a significant impact on the success of writing summaries. This study has shown that Turkish teacher candidates have a lot of misinformation about summarizing, and that their knowledge and skills have increased through the teaching of summarization strategies.

\subsection{Recommendations}

This study is limited to narrative texts. Experimental studies on the summarization of different types of texts may improve both the summarization knowledge and skills of teacher candidates and contribute to the literature as the use of strategy varies depending on the structure of a text.

Source texts for this study were determined based on expert opinions. However, one of these texts has been described as a difficult text to summarize by the students because of the author's style. Text selection should be made after a pre-implementation in summarization studies.

Teaching of summarization strategies should be included in the curricula of educational organizations at every stage since primary school in order to increase the use of strategy and to have more successful summary texts. If this is the case, the teacher candidates would come to education faculties with their summarization abilities fully developed.

Summarization success increases if summarization is done repeatedly. Giving feedback on criteria based on the summarization strategies has been effective in reaching the goal of this study by exemplifying why the correct summaries are correct and what mistakes the wrong summaries contain. Application-based studies should be conducted to provide knowledge and skills about summarization strategies in the training process of Turkish teacher candidates and feedback should be given. Application-based studies can be included in courses which focus on reading, writing and listening.

\section{REFERENCES}

[1] F. Susar, N. Akkaya. (2009). University students for using the summarizing strategies. Procedia Social and Behavioral Sciences, 1, 2496-2499.

[2] Z. Bahap Kudret, B. Baylik. (2016). Reading comprehension and summarizing skills of successful and unsuccessful fourth grade readers. Ankara University Faculty of Educational Sciences Journal of Special Education, 17(3), 317-346.

[3] P. N. Winograd. (1983). Staregic difficulties in summarizing texts. Retrieved from https://www.ideals.illinois.edu/bitstream/handle/2142/1800 6/ctrstreadtechrepv01983i00274 opt.pdf?sequence $=1$ on 19.06.2018.

[4] Ş. D. Belet. (2005). Effectiveness of learning strategies over reading comprehension, writing skills and learners' attitudes towards Turkish course. (Unpublished doctoral dissertation). Anadolu University, Eskişehir, Turkey.

[5] C. Dollins. (2012). comprehending expository texts: Scaffolding students through writing summaries. The California Reader, 45(2), 22-28.

[6] H. Khoshsima, F. Rezaeian Tiyar. (2014). the effect of summarizing strategy on reading comprehension of Iranian intermediate EFL learners. International Journal of Language and Linguistics, 2(3), 134-139.

[7] M. Pakzadian, A. E. Rasekh. (2012). The Effects of using summarization strategies on Iranian EFL learners' reading comprehension. English Linguistics Research, 1(1), 118-125.

[8] J. R. Nelson, D. J. Simith, J. M. Dodd. (1992). The effects of teaching a summary skills strategy to students identified as learning disabled on their comprehension of science text. Education and Treatment of Children, 15(3), 228-243.

[9] Ş. Tok, N. Bayazit. (2007). The effects of summarizing and note taking strategies on the comprehension and retention of third grade primary school students. Eurasian Journal of Educational Research, 28, 113-122.

[10] C. Bazerman. (2010). Summarizing: The author's main ideas. In Informed writer: Using sources in the disciplines (5. ed., p.50-66). Retrieved from https://writing.colostate.edu/textbooks/informedwriter/cha pter4.pdf on 28.06.2018.

[11] A. L. Hahn, R. Garner. (1985). Synthesis of research on students' ability to summarize text. Educational Leadership, 42(5), 52-55.

[12] B. F. Clouse. (2004). Progressions with readings. (Sixth Edition). Longman.

[13] M. Hill. (1991). Writing summaries promotes thinking and learning across the curriculum but why are they so difficult to write? Journal of reading, 34(7), 536-539.

[14] R. Friend. (2001). Teaching summarization as a content area reading strategy. Journal of Adolescent \& Adult Literacy, 44(4), 320-329.

[15] L. Beyreli, Z. Çetindağ, A. Celepoğlu. (2005). Yazılı ve sözlü anlatım. Ankara: Pegem A Yayıncılık.

[16] F. Güneş. (2007). Türkçe öğretimi ve zihinsel yapılandırma. Ankara: Nobel Yayın Dağıtım.

[17] H. Karatay, H. Güngör, K. K. Bolat, S. Okur. (2013). 6, 7 ve 8. sınıf öğrencilerinin özetleme becerileri. C. Demir ve H. Parlakyıldız (Ed.), Prof. Dr. Abdurrahman Güzel'e Armağan Türkçenin Eğitim ve Öğretimi içinde (s. 277-298). Ankara: Akçă̆ Yayınları.

[18] S. Ateş. (2011). Evaluation of fifth-grade Turkish course learning and teaching process in terms of comprehension instruction. (Unpublished doctoral dissertation). Gazi University, Ankara, Turkey.

[19] P. Bulut. (2013). the evaluation of summarizing strategies 
of the primary school 5th grade students and teachers: Turkish lesson example. (Unpublished doctoral dissertation). Gazi University, Ankara, Turkey.

[20] Ş. Dilidüzgün. (2013). from reading to summary writing in secondary school Turkish lessons. Ankara University Journal of Faculty of Educational Sciences, 46(2), 47-68.

[21] M. S. Rose. (2001). in defence of summarization. College of The Bahamas Research Journal, 10, 29-34.

[22] A. L. Brown, J. D. Day. (1983). Macrorules for summarizing texts: The development of expertise. Journal of Verbal Behavior, 22(1), 1-14.

[23] A. L. Brown, J. D. Day, R. S. Jones. (1983). the development of plans for summarizing texts. Child Development, 54, 968-979.

[24] H. Ülper, H. Yazıc1 Okuyan. (2010). Quality of written summary texts: An analysis in the context of gender and school variables. Procedia Social and Behavioral Sciences, 2, 1057-1063

[25] H. Karatay, S. Okur. (2012). Prospective teachers' summarizing skills in narrative and expository texts. International Journal of Social Science, 5(7), 399-420.

[26] Y. Doğan, H. Özçakmak. (2014). Evaluation of pre-service Turkish language teachers' summarizing skills for the texts listened. Mustafa Kemal University Journal of Social Sciences Institute, 11(28), 153-176.

[27] A. Benzer, A. Sefer, Z. Ören, S. Konuk. (2016). A student-focused study: Strategy of text summary writing and assessment rubric. Education and Science, 41(186), 163-183.

[28] B. Eyüp, M. Z. Stebler, S. Uzuner Yurt. (2012). Tendencies of pre-Service Turkish teachers in the use of summarizing strategies. Journal of Language and Literature Education, $1(1), 22-30$.

[29] İ. Görgen. (2015). the extent to which pre-service Turkish language and literature teachers could apply summarizing rules in informative texts. Educational Research and Reviews, 10(3), 308-312.

[30] H. Kurnaz, Ş. Akaydın. (2015). Informative and narrative texts summarization skills of Turkish language teacher candidates. Erzincan Univesity Journal of Social Sciences Institute, Special Issue II, 141-156.

[31] H. Yazıcı Okuyan, Y. G. Gedikoğlu. (2011). Qualitative Features of Written Summary Texts Produced by Teachers. Gaziantep Univesity Journal of Social Sciences Institute, 10 (2), 1007-1020.

[32] İ. Görgen. (1999). Özetleme becerisinin öğrencilere ögretimi. Journal of Education for Life, 62, 22-28.

[33] H. Ülper, S. Karagül. (2011). Özetleme becerisinin kazandırılmasına yönelik etkinlikler: Ders kitapları temelinde bir araştırma. (Ed.: V. D. Günay, Ö. Fidan, B. Çetin \& F. Yıldız), Türkçe öğretimi üzerine çalışmalar içinde (s.145-155). İzmir: Dokuz Eylül Üniversitesi

\footnotetext{
${ }^{\mathrm{i}}$ This article is an extended version of oral presentation which was
}

Yayınları.

[34] W. Kintsch, T. A. van Dijk. (1978). toward a model of text comprehension and production. Psychological Review, 85(5), 363-394.

[35] Ş. Dilidüzgün, Ş. Genç. (2014). Metin türü odaklı özet çıkarma çalışmalarının özet çıkarma becerisini geliştirmeye etkisi. (Ed. İşeri, K. vd) Türkçe eğitiminde kuramsal ve uygulamalı çalışmalar içinde (s. 87-113). Ankara: Pegem Akademi.

[36] J. D. Wilhelm, D. Fisher, K. A. Hinchman, D. O’Brien, T. Raphael, C. H. Shanahan. (2007). Literature reading with purpose. USA: Glencoe/McGraw-Hill Companies.

[37] B. B. Armbruster, T. H. Anderson, J. Ostertag. (1986). Does text structure/summarization instruction facilitate learning from expository text? Technical Report Center for the Study of Reading, University of Illinois at Urbana Champaign.

[38] V. Anderson, S. Hidi, C. Babadoğan. (1991). Özetlemenin ögrencilere öğretimi. Ankara Üniversitesi Eğitim Bilimleri Fakültesi Dergisi, 24, 587-594.

[39] W. G. Lehnert. (1981). Plot units and narrative summarization. Cognitive Science, 4, 293-331.

[40] L. Yuan ke, M. Hoey. (2014). Strategies of writing summaries for hard news texts: A text analysis approach. Discourse Studies, 16(1), 89-105.

[41] K. Blanchard, C. Root. (2004). ready to write more: from paragraph to essay (2nd Ed.). USA: Longman.

[42] İ. Görgen, S. Altıntaş. (2015). Analyzing pre-service teachers' skill-level on summarizing informative texts. Procedia Social and Behavioral Sciences, 174, 3005-3010.

[43] C. Erdem. (2012). Summation strategies use preferences of Turkish language and literature teacher candidates and study of a text linguistics summation. Journal of Language and Literature Education, 1(3), 36-52.

[44] N. Karasar. (2009). Bilimsel araştırma yöntemi. (20. Ed.) Ankara: Nobel Yayın Dağıtım.

[45] A. Yıldırım, H. Şimşek. (2013). Sosyal bilimlerde nitel araştırma yöntemleri. (9. Ed.) Ankara: Seçkin Yayıncılık.

[46] National Reading Panel. (2000). Report of the national reading panel: teaching children to read. Bethesda, MD: National Institute of Child Health and Human Development. Retrieved from https://www1.nichd.nih.gov/publications/pubs/nrp/docume nts/report.pdf 27.06.2018

[47] Y. Chen, S. Su. (2012). A genre-based approach to teaching EFL summary writing. ELT Journal, 66(2) doi:10.1093/elt/ccro61

[48] N. Topçu. (2015). 3N learning model with paired reading summarization and individual reading summarization implementation's impact on learning levels and remembering. (Unpublished doctoral dissertation). Gaziosmanpaşa University, Tokat, Turkey

presented at 2nd International Symposium of Limitless Education and Research (April 26-28, 2018, Bodrum-Muğla) 